\title{
PENGARUH DEBT TO ASSET RATIO, RETURN ON ASSET EARNINGPER SHARE TERHADAP HARGA SAHAM PADA PERUSAHAAN FARMASI YANG TERDAFTAR DI BURSA EFEK INDONESIAPERIODE 2015-2019
}

\author{
Dody Salden Chandra \\ Prodi Manajemen Fakultas Ekonomi dan Bisnis \\ Universitas Muhammadyah Sumatera Utara \\ dodysalden@umsu.ac.id
}

\begin{abstract}
ABSTRAK
This study aims to determine the effect of Debt to Asset Ratio, Return on Investment, and Earning Per Share on Stock Prices. With a population of pharmaceutical companies listed on the Indonesia Stock Exchange for the 2015-2019 period. This research uses an Associative Quantitative approach. The sample in this study was determined by purposive sampling technique, so that the samples that met the criteria in the sampling for this study were 8 companies. Data collection techniques in this study using documentation techniques, with data analysis techniques using Multiple Linear Regression Analysis. The results of this study concluded that partially there is no effect on Debt to Asset Ratio on Stock Prices, partially negative effect on Return on Investment Stock Prices, Partially there is a positive influence between Earning Per Share on Stock Prices, and simultaneously Debt to Asset Ratio, Return on Investment, and Earning Per Share have a significant effect on share prices in pharmaceutical companies listed on the Indonesia Stock Exchange for the 2015-2019 period.
\end{abstract}

\section{Keywords: Debt to Equity Ratio, Net Profit Margin, Earning Per Share, Stock Price}

\section{Pendahuluan}

Pasar modal merupakan pertemuan antara pihak yang memiliki kelebihan dana dengan pihak yang membutuhkan dana dengan cara memperjual belikan sekuritas. Setiap perusahaan yang listing di Bursa Efek Indonesia atau go public pasti menerbitkan saham yang dapat dimiliki oleh investor. Tetapi harga saham sangatlah fluktuatif atau berubah-ubah, padalhan pihak investor sangatla ingin harga sahamnya tinggi dan tidak perna turun (Hutami, 2012).

Setiap investor atau calon investor memiliki tujuan tertentu yang ingin dicapai melalui keputusan investasi yang diambil. Pada umumnya motif investasi adalah memperoleh keuntungan, keamanan, dan pertumbuhan dana yang ditanamkan. Untuk itu dalam melakukan investasi dalam bentuk saham investor harus melakukan analisis terhadap faktor-faktor yang mempengaruhi kondisi perusahaan emiten. Tujuannya agar para investor mendapat gambaran yang lebih jelas terhadap kemampuan perusahaan untuk terus tumbuh dan berkembang pada masa yang akan datang (Pratama, 2014).

Salah satu bentuk investasi yang dapat dilakukan oleh investor dalam memperoleh keuntungan yaitu berupa saham maupun obligasi. Saham merupakan surat berharga yang menunjukan kepemilikan atau penyertaan investor dalamsuatu perusahaan yang terdaftar di pasar modal. Obligasi merupakan surat berharga yang berisi kontrak pengakuan hutang atas pinjaman yang diterima oleh penerbit obligasi dari pemberi pinjaman (pemodal). Ada dua keuntungan yang dapat dinikmati oleh investor jika berinvestasi saham yaitu memperoleh deviden dan capital gain. Deviden merupakan pembagian keuntungan kepada pemegang saham yang sebanding dengan jumlah lembar saham yang dimiliki. Sedangkan capital gain memperoleh keuntungan yang diperoleh pemegang saham ketika menjual sahamnya terdapat selisih antara harga jual dan harga beli (Selfiyanti, 2017). 


\section{Kajian Teori \\ 2.1 Harga Saham}

Menurut Fahmi (2015, hal. 67) saham adalah tanda bukti penyerahan kepemilikan modal/dana pada suatu perusahaan, kertas yang tercantum dengan jelas nilai nominal, nama perusahaan dan diikuti dengan hak dan kewajiban yang dijelaskann kepada setiap pemegangnya. Menurut Salim ( 2010, hal. 5) Saham adalah bentuk penyertaan modal dalam sebuah perusahaan. Ketika kita memiliki saham sebuah perusahaan, bisa ikatakan kita memiliki perusahaan tersebutsebesar persentase tertentu sesuai dengan jumlah lembar saham yang kita miliki. Menurut Widoatmodjo (2008, hal. 23) Harga saham adalah angka yang menunjukan besar perubahan harga dari harga sebelumnya, perubahan hari ini dibaningkan dihari sebelumnya.

Harga saham yang cukup tinggi akan memberikan keuntungan, yaitu berupa capital gain dan citra yang lebih baik bagi perusahaan sehingga memudahkan bagi manajemen untuk mendapatkan dana dari luar perusahaan.

Investor dipasar modal perlu memiliki sejumlah informasi yang akurat berkaitan tentang dinamika harga saham agar bisa mengambil keputusan tentang saham perusahaan yang layak untuk dipilih dan dibeli. investor yang ingin menginvestasikan dananyadipasar modal yang berupa saham,investor harus mengetahui harga saham dalam menentukan pemberlian saham pada suatu perusahaan

\subsection{Debt to Asset Ratio}

Menurut Hery (2018, hal. 142) rasio solvabilitas merupakan rasio yang menggambarkan kemampuan perusahaan dalam memenuhi seluruh kewajibannya. Saham halnya dengan rasio likuiditas, rasio solvabilitas juga untuk kepentingan analisis kredit atau analisis rasio keuangan. Debt to Assets Ratio menurut Kasmir (2015:156): merupakan rasio utang yang digunakan untuk mengukur perbandingan antara total utang dengan total aktiva. Dengan kata lain, seberapa besar aktiva perusahaan berpengaruh terhadap pengelolaan aktiva. Pengertian Debt to Assets Ratio menurut Fahmi (2011:127): Rasio yang melihat perbandingan utang perusahaan, yaitu diperoleh dari perbandingan total utang dibagi total aset. Sehingga dapat disimpulkan bahwa rasio ini mengukur presentase besarnya dana yang berasal dari hutang baik jangka pendek maupun jangka panjang. Kreditur lebih menyukai Total Debt to total Assets Ratio atau Debt Ratio yang rendah sebab tingkat keamanannya semakin baik.

\subsection{Return on Investment}

Rasio return on investment (ROI) atau pengembalian investasi, atau ditulis juga dengan return on total asset (ROA). Rasio ini melihat sejauh mana investasi yang telah ditanamkan mampu memberikan pengembalian keuntungan sesuai dengan yang diharapkan. Investasi tersebut sebenarnya sama dengan asset perusahaan yang ditanamkan atau ditempatkan. Pengertian Return on Investment (ROI) menurut Kasmir (2015:198): Rasio ini merupakan rasio yang menunjukkan hasil (return) atas jumlah aktiva yang digunakan dalam perusahaan. ROI juga merupakan suatu ukuran tentang efektivitas manajemen dalam mengelola investasinya.

\subsection{Earning Per Share}

Menurut Fahmi (2015, hal. 82) Earning Per Share atau pendapatan per lembar saham adalah bentuk pemberian keuantungan yang diberikan kepada para pemegang saham darri setiap lembar sagam yang dimiliki. Menurut Kasmir (2010, hal. 115) Earning Per Share merupakan rasio untuk mengukur keberhasilan manajeman dalam mencapai keuntungan bagi pemegang saham. Rasio ini rendah berati manajeman belum berhasil untuk memuaskan pemegang saham, sebaliknya rasio yang tinggi, maka kesejahteraan pemegang saham meningkat. Earning Per Share adalah tingkat kemampuan yang diperoleh pemegang saham 
dalam tiap lembar saham yang dimiliki. Earning Per Share didapat dari laba bersih setelah bunga dan pajak dibagi dengan jumlah saham biasa yang beredar. Informasi yang terdapat di dalam Earning Per Share menggambarkan besarnya jumlah laba bersih perusahaan setelah bunga dan pajak yang dibagikan kepada para pemegangsaham

\subsection{Hipotesis}

Hipotesis berkaitan erat dengan teori. Menurut Sugiyono (2017, hal. 64) hipotesis merupakan jawaban sementara terhadap rumusan masalah penelitian, dimana rumusan masalah penelitian telah dinyatakan dalam bentuk kalimat pernyataan. Berasarkan masalah yang diketemukan sebelumnya maka dirumuskanhipotesis adalah sebagai berikut:

1. Debt to Asset Ratio (DAR) berpengaruh positif dan signifikan terhadap Harga Saham pada perusahaan Farmasi yang terdaftar di Bursa Efek Indonesia periode 2015-2019

2. Return on Investment (ROI) berpengaruh positif dan signifikan terhadap Harga Saham pada perusahaan Farmasi yang terdaftar di Bursa Efek Indonesia periode 2015-2019

3. Earning Per Share (EPS) berpengaruh positif dan signifikan terhadap Harga Saham pada perusahaan Farmasi yang terdaftar di Bursa Efek Indonesia periode 2015-2019

4. Debt to Asset Ratio, Return on Investment, Earning Per Share secara simultan berpengaruh terhadap Harga Saham pada perusahaan Farmasi ya ng terdaftar di Bursa Efek Indonesia periode 2015-2019

\section{Metode Penelitian}

Pendekatan penelitian yang digunakan alam penelitian ini adalah pendekatan asosiatif populasi dalam penelitian ini adalah Perusahaan Farmasi yang terdaftar di Bursa Efek Indonesia yang berjumlah 10 perusahaan. Sampel yang diambil menggunakan purposive sampling berjumlah 8 perusahaan. Teknik pengumpulan data pada penelitian menggunakan teknik dokumentasi. Teknik analisis data yang digunakan pada penelitian ini adalah Teknik analisis data penelitian ini menggunakan Analisis Regresi Linear Berganda.

\section{Hasil Dan Pembahasan}

\subsection{Hasil Penelitian}

Uji Normalitas

Pengujian normalitas data dilakukan untuk melihat apakah dalam model regresi, variabel bebas dan variabel terikat atau keduanya memiliki distribusinormal atau tidak. Uji normalitas yang digunakan dalam penelitian ini yaitu Uji Kolmogrov Smirnov (K-S) dengan asumsi berdasarkan kriteria tersebut:

a. Jika angka signifikan $>0.05$ maka data berdistribusi normal.

b. Jika angka signifikan $<0.05$ maka data tidak berdistribusi normal.

Adapun hasil uji Kolmogrov Smirnov dalam penelitian ini dapat dilihat pada tabel sebagai berikut:

Tabel 4.1

Uji Normalitas

One-Sample Kolmogorov-Smirnov Test

\begin{tabular}{|l|r|}
\hline & Unstandardized Residual \\
\hline $\mathrm{N}$ & 40 \\
Normal Parameters ${ }^{\mathrm{a}}$ Mean & .0000000 \\
Std. Deviation & $2.06080399 \mathrm{E} 2$ \\
Most Extreme Differences Absolute & .173 \\
\multicolumn{1}{|c|}{ Positive } & .173 \\
Negative & -.132 \\
Kolmogorov-Smirnov Z & 1.130 \\
Asymp. Sig. (2-tailed) & .126 \\
\hline
\end{tabular}


a. Test distribution is Normal.

Sumber: Hasil Pengelolahan Data SPSS

Dari hasil pengolahan data pada tabel diatas diperoleh besarnya nilai KolmogrovSmirnov adalah 1.130 dan signifikan pada 0,126. Nilai signifikan $0.126>0.05$ sehingga data berdistribusi normal.

Adapun metode lain mengetahui normalitas adalah dengan melihat dari hasil Normal Probability Plot. Normalitas data dapat dilihat dari penyebaran data yang mengikuti arah garis diagonal pada grafik Normal P-plot. Hasil Normal Probability Plot dapat dilihat pada gambar sebagai berikut:

Normal P-P Plot of Regression Standardized Residual

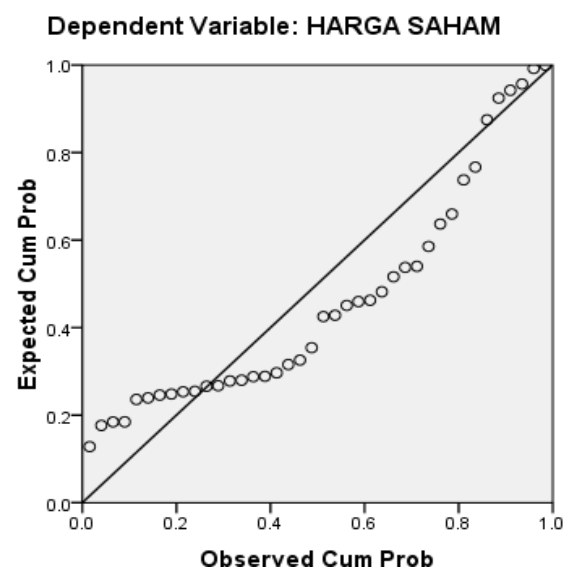

Gambar 4.1

Hasil Uji Heteroskedastisitas

Pada grafik normal $p$-plot terlihat pada gambar bahwa data menyebardisekitar garis diagonal dan mengikuti arah garis diagonal, maka dapat disimpulkan bahwa model regresi telah memenuhi asumsi normalitas.Hal ini menyimpulkan bahwa metode regresi berdistribusi normal dan layak untuk dianalisis.

\section{Uji Multikolinieritas}

Multikolinearitas digunakan untuk menguji apakah pada model regresiditemukan adanya korelasi yang kuat antar variabel bebas.Model regresi yangbaik seharusnya tidak terjadi korelasi diantara variabel bebas. Untuk mendeteksi ada atau tidaknya multikoliniearitas di dalam model regresi adalah sebagai berikut: dapat dilihat dari nilai tolerance dan Variance Inflation Factor $(V I F)<10$, berarti tidak terdapat multikoliniearitas

Tabel 4.2

Uji Multikolinearitas

Coefficients $^{\mathbf{a}}$

\begin{tabular}{|c|c|c|}
\hline \multirow[b]{2}{*}{ Model } & \multicolumn{2}{|c|}{ Collinearity Statistics } \\
\hline & Tolerance & VIF \\
\hline (Constant) & & \\
\hline DAR & .339 & 2.778 \\
\hline ROI & .375 & 2.645 \\
\hline EPS & .600 & 2.121 \\
\hline
\end{tabular}

a. Dependent Variable: HARGA SAHAM

Sumber: Hasil Pengelolahan Data SPSS

Dari data pada tabel diatas dapat diketahui bahwa nilai variance inflation factor (VIF) untuk variabel Debt to Asset Ratio sebesar 2.788, vaiabel Return on Investemnt sebesar 2.645, dan variabel Earning Per Share sebesar 2.121 demikian juga dengan Tolerance pada variabel 
Debt to Asset Ratio sebesar 0,339, dan variabel Return on Investemn tsebesar 0,375 dan variabel Earning Per Share sebesar 0,600. Dari masing-masing variabel nilai Tolerance lebih besar dari 0,1 sehingga dapat disimpulkan bahwa tidak terjadi multikoliniertas. Dan nilai VIF lebih kecil dari 10, maka dapat disimpulkan bahwa tidak terdapat multikolinieritas.

\section{Uji Heteroskedastisitas}

Heterokedastisitas digunakan untuk menguji apakah dalam model regresi, terjadi ketidaksamaan varian dan residual satu pengamatan yang lain. Jika varian residual dari satu pengamanan yang lain tetap, maka regresi yang baik adalahyang homokedastisitas atau tidak terjadi heterokedastisitas. Jika ada pola tertentu, seperti titik yang membentuk pola yang teratur (bergelombang, melebar kemudianmenyempit), maka hal ini akan mengindikasikan telah terjadi heterokedastisitas. Jika ada pola yang jelas, serta titik-titik menyebar diatas dan dibawah angka 0 pada sumbu Y, maka tidak terjadi heterokedastisitas.

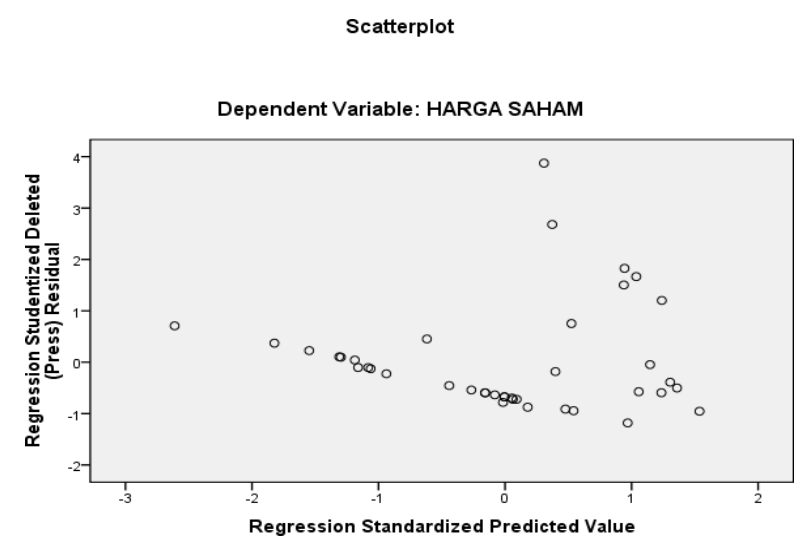

Gambar 4.2 Hasil Uji Heteroskedastisitas

Sumber: Hasil Pengolahan Data SPSS

Berdasarkan gambar Scatterplot diatas terlihat bahwa titik-titik menyebar secara acak, tidak membentuk pola yang jelas (bergelombang, melebar dan menyempit), serta tersebar baik diatas maupun dibawah angka 0 pada sumbu $Y$. Dengan demikian tidak terjadi heteroskedastisitas pada model regresi.

\section{2. Analisis Data}

\section{Regresi Linier Berganda}

Dalam penelitian ini analisis regresi linier berganda untuk mengetahuipengaruh dari masing-masing variabel bebas terhadap variabel terikat.Berikutadalah hasil pengolahan data dengan menggunakan SPSS versi 16.

Tabel 4.3

Uji Regresi Linier Berganda

Coefficients $^{\text {a }}$

\begin{tabular}{|ll|r|r|r|}
\hline \multirow{2}{*}{ Model } & \multicolumn{2}{|c|}{} & \multicolumn{2}{|l|}{$\begin{array}{l}\text { Standardized } \\
\text { Coefficients }\end{array}$} \\
\cline { 2 - 4 } & Unstandardized Coefficients & Beta \\
\hline 1 & (Constant) & 273.647 & 145.334 & \\
DAR & -3.473 & 2.330 & -.572 \\
ROI & -5.269 & 8.650 & -.612 \\
EPS & .265 & .468 & .170 \\
\hline
\end{tabular}

a. Dependent Variable: HARGA SAHAM

Sumber: Hasil Pengelolahan Data SPSS

Hasil tersebut dimasukan kedalam bentuk persamaan regresi linierberganda sehingga diketahui persamaan sebagai berikut: 
Keterangan:

Nilai koefisien regresi dari Debt to Asset Ratio adalah -3.473 , yakni bernilai negatif. Nilai tersebut diinterpretasikan Debt to Asset Ratio berpengaruh negatif terhadap harga saham. Nilai koefisien regresi dari Return on Investemntadalah - 5.269, yakni bernilai negatif. Nilai tersebut diinterpretasikan Return on Investemntberpengaruh negatif terhadap harga saham. Nilai koefisien regresi dai Earning PerShare adalah positif 0,265, yakni bernilai positif. Nilai tersebut dapat diinterpretasikan Earning Per Share berpengaruh positif terhadap harga saham. Uji Hipotesis Uji t (Parsial)

Uji t digunakan untuk menguji koefisien regresi secara individual, pengujian ini dilakukan untuk mengetahui apakah secara parsial masing-masing variabel bebas mempunyai pengaruh signifikan atau tidak terhadap variabel terikat.

Tabel 4.4 Uji t (parsial)

Coefficients $^{\mathrm{a}}$

\begin{tabular}{|c|c|c|c|c|c|}
\hline \multirow[b]{2}{*}{ Model } & \multicolumn{2}{|c|}{ Unstandardized Coefficients } & \begin{tabular}{|l} 
Standardized \\
Coefficients
\end{tabular} & \multirow[b]{2}{*}{$\mathrm{T}$} & \multirow[b]{2}{*}{ Sig. } \\
\hline & $\mathrm{B}$ & Std. Error & Beta & & \\
\hline (Constant) & 273.647 & 145.334 & & 3.256 & .002 \\
\hline DAR & -3.473 & 2.330 & -.572 & -1.903 & .065 \\
\hline ROI & -5.269 & 8.650 & -.612 & -2.938 & .006 \\
\hline EPS & & & & .572 & .571 \\
\hline
\end{tabular}

a. Dependent Variable: HARGA SAHAM

Sumber: Hasil Pengelolahan Data

Pengaruh Debt to Asset Ratio terhadap Harga Saham

Berdasarkan hasil pengujian diatas secara parsial pengaruh Debt to Asset Ratio terhadap Harga Saham. Nilai thitung untuk variabel Debt to Asset Ratio adalah -1.903 dan tabel dengan $\alpha=5 \%$ diketahui sebesar 2.026. Dengan demikian

-1.903 >-2.026 dan nilai signifikan sebesar 0.065 (lebih besar dari 0.05) artiya $\mathrm{H}_{\mathrm{o}}$ ditolak dan $\mathrm{H}_{\alpha}$ diterima. Berdasarkan hasil tersebut maka disimpulkan bahwasecara parsial tidak berpengaruh dan tidak signifikan Debt to Asset Ratio terhadap Harga Saham.

\section{Pengaruh Return on Investemntterhadap Harga Saham}

Berdasarkan hasil pengujian diatas secara parsial pengaruh Return on Investemntterhadap Harga Saham. Nilai thitung untuk variabel Return on Investemntadalah 2.938 dan $\mathrm{t}_{\text {tabel }}$ dengan $\alpha=5 \%$ diketahui sebesar 2.026. Dengan demikian

$-2.938<-2.026$ dan nilai signifikan sebesar 0.006 (lebih kecil dari 0.05) artiya $\mathrm{H}_{\mathrm{o}}$ ditolak dan $\mathrm{H}_{\alpha}$ diterima. Berdasarkan hasil tersebut maka disimpulkan bahwa secara parsial berpengaruh negatif dan signifikan Net Pofit Margin terhadap Harga Saham.

\section{Pengaruh Earning Per Share terhadap Harga Saham}

Berdasarkan hasil pengujian diatas secara parsial pengaruh Earning Per Share terhadap Harga Saham. Nilai thitung untuk variabel Earning Per Share adalah 0,572 dan $\mathrm{t}_{\text {tabel }}$ dengan $\alpha=5 \%$ diketahui sebesar 2.026. Dengan demikian $(0,572<2.026)$ dan nilai signifikan sebesar 0,571 (lebih besar dari 0.05) artiya $\mathrm{H}_{\mathrm{o}}$ diterima dan $\mathrm{H}_{\alpha}$ ditolak. Berdasarkan hasil tersebut maka disimpulkan bahwa ada pengaruh positif dan tidak signifikan antara Earning Per Share terhadap HargaSaham.

Tabel 4.5

Uji f (simultan)

anova

\begin{tabular}{|l|r|r|r|r|r|l|}
\hline \multicolumn{2}{|l|}{ Model } & Sum of Squares & Df & Mean Square & F & Sig. \\
\hline 1 & Regression & 424682.406 & 3 & 141560.802 & 3.077 & $.040^{\mathrm{a}}$ \\
\hline & Residual & 1656296.099 & 36 & 46008.225 & & \\
\hline Total & 2080978.505 & 39 & & & \\
\hline
\end{tabular}


a. Predictors: (Constant), EPS, ROI, DAR

b. Dependent Variable: HARGA SAHAM

Sumber: Hasil Pengelolahan Data SPSS (2018)

Berdasarkan hasil pengujian diatas secara simultan, maka dapat diperoleh nilai $\mathrm{F}_{\text {hitung }}$ sebesar 3.077 dan $\mathrm{F}_{\text {tabel }}$ diketahui sebesar 2.87.Berdasarkan hasil tersebut maka dapat diketahui bahwa $F_{\text {hitung }}>F_{\text {tabel }}(3.077>2.87$ ), dan signifikansiadalah sebesar 0.040 (lebih kecil dari 0.05) ini berarti $\mathrm{H}_{\mathrm{o}}$ ditolak dan $\mathrm{H}_{\mathrm{o}}$ diterima. Jadi dapat disimpulkan bahwa variabel Debt to Equity Ratio, Net Profit Margin, dan Eaning Per Share secara simultan berpengaruh signifikan terhadap Harga saham pada perusahaan Farmasi yang terdaftar di Bursa Efek Indonesia.

\section{Koefisien Determinasi}

Koefisien determinasi digunakan untuk mengetahui persentasi besarnya pengaruh variabel terikat yaitu dengan mengkuadrat koefisien yang ditemukan.Dalam penggunanya koefisien determinasi ini dinyatakan dalm persentase (\%).Untuk mengetahui sejauh mana kontribusi atau persentasepengaruh Debt to Equity Ratio,Net Profit Margin, Earning Per Share maka dapat diketahui melalui uji determinasi.

Tabel 4.6.

\section{Koefisien Determinasi} Model Summary ${ }^{\mathrm{b}}$

\begin{tabular}{|c|c|c|c|c|c|}
\hline \multirow[b]{2}{*}{ Model } & \multirow[b]{2}{*}{$\mathrm{R}$} & \multirow[b]{2}{*}{ R Square } & \multirow[b]{2}{*}{$\begin{array}{l}\text { Adjusted R } \\
\text { Square }\end{array}$} & \multirow{2}{*}{$\begin{array}{l}\text { 1. Error of the } \\
\text { Estimate }\end{array}$} & Durbin-Watson \\
\hline & & & & & \\
\hline 1 & $.452^{a}$ & .204 & & \begin{tabular}{l|l}
814.49528 \\
\end{tabular} & 2.368 \\
\hline
\end{tabular}

a. Predictors: (Constant), EPS, ROI, DAR

b. Dependent Variable: HARGA SAHAM

Sumber: Hasil Pengelolaan Data Spss

Berdasarkan tabel diatas menunjukkan bahwa hasil nilai $R$-Squaresebesar 0.204 menunjukkan bahwa korelasi atau hubungan Harga Saham (variabel dependent) dengan Debt to Equity Ratio, Return on Investemntdan Earning Per Share (variabel independent) mempunyai tingkat hubungan yaitu sebesar20,4\%.

\subsection{Pembahasan}

\section{Pengaruh Debt to Asset Ratio terhadap Harga Saham}

Hasil penelitian yang diperoleh mengenai Pengaruh Debt to Asset Ratio terhadap Harga Saham pada perusahaan Farmasi yang terdaftar di Bursa Efek Indonesia. Hasil uji secara parsial menunjukkan bahwa nilai thitung untuk variabel Debt to Asset Ratio adalah 1.903 dan $t_{\text {tabel }}$ dengan $\alpha=5 \%$ diketahui sebesar 2.026. Dengan demikian -1.903>-2.026 dan nilai signifikan sebesar 0.065 (lebih besar dari 0.05) artiya $\mathrm{H}_{\mathrm{o}}$ ditolak dan $\mathrm{H}_{\alpha}$ diterima. Berdasarkan hasil tersebut maka disimpulkan bahwa secara parsial tidak berpengaruh dan tidak signifikan Debt to Asset Ratio terhadap Harga Saham.

Menurut kasmir (2015, hal. 158) Debt to Asset Ratio merupakan rasio yang digunakan untuk menilai utang dengan modal. Rasio ini dibari dengan cara membandingkan antara seluluh utang, termaksut utang lancar dengan seluruhekuitas. Rasio ini berguna untuk mengetahui jumlah dana yang disediakan peminjam (kreditor) dengan pemilik perusahaan. Dengn kata lain rasio ini berfungsi untuk mengetahui setiap rupiah modal sendiri yang dijadikan untuk jaminan utang.

Hasil penelitian ini sejalan dengan hasil penelitian yang menyatakan bahwa Debt to Asset Ratio tidak berpengaruh terhadap harga saham (Utami \& Darmawan, 2018 ; Sriwahyuni \& Saputra, 2017 ; Nurfadilah 2011) maka dapat diartikan bahwa secara parsial Debt to Asset Ratio tidak berpengaruh dan tidak signifikan terhadap harga saham.

Namun hasil penelitian ini bertentangan dengan penelitian yang menyatakan bahwa 
Debt to Asset Ratio berpengaruh terhadap harga saham (Batubara, 2017 ; Alfiah \& Diyani, 2017 ; Dewi \& Suaryana, 2013) maka dapat disimpulkan bahwa ada pengaruh positif dan signifikan antara Debt to Asset Ratio terhadap harga saham.

\section{Pengaruh Return on Investemnt terhadap Harga Saham}

Hasil penelitian yang diperoleh mengenai Pengaruh Return on Investemnt terhadap Harga Saham pada perusahaan Farmasi yang terdaftar di Bursa Efek Indonesia. Hasil uji secara parsial menunjukkan bahwa nilai $t_{\text {hitung }}$ untuk variabel Return on Investemnt adalah 2.938 dan $\mathrm{t}_{\text {tabel }}$ dengan $\alpha=5 \%$ diketahui sebesar 2.026. Dengan demikian $-2.938<-2.026$ dan nilai signifikan sebesar 0.006 (lebih kecil dari 0.05) artiya $\mathrm{H}_{\mathrm{o}}$ ditolak dan $\mathrm{H}_{\alpha}$ diterima. Berdasarkan hasil tersebut maka disimpulkan bahwa secara parsial berpengaruh negatif dan signifikan Return on Investment terhadap Harga Saham.

Menurut Hery (2018, hal. 198) Margin laba bersih merupakan rasio yang digunakan untuk mengukur besarnya persentase laba bersih atas penjualan bersih. Rasio ini dihitung dengan membagi laba bersih terhadap penjualan bersih. besar kecilnya ROI akan menggambarkan bahwa kinerja suatu perusahaan semakin baik atau buruk yang akan berdampak pada pemegang saham apakah akan meningkatkan kepercayaan investor untuk menanamkan modalnya dan memperoleh keuntungan atau bahkan membuat para pemegang saham mendapatkan laba yang rendah.

Hasil ini didukung oleh penelitian yang menyatakan bahwa Return on Investemn tberpengaruh Negatif dan signifikan terhadap harga saham (Egam \& Ilat, 2017 ; Azmi dkk, 2016 ; Aryani \& Zulkifli, 2016) dapat disimpulkan bahwa Return on Investement tmemiliki pengaruh negatif terhada harga saham.

Namun hasil ini tidak sejalan dengan penelitian yang menyatakan bahwa Return on Investemnt berpengaruh positif dan signifikan terhadap harga saham (Hutami, 2012 ; Rimbani, 2016 ; Anisma, 2012) dapat disimpulkan bahwa Return on Investemnt berpengaruh positif dan signifikan terhadap harga saham.

\section{Pengaruh Earning Per Share terhadap Harga Saham}

Hasil penelitian yang diperoleh mengenai Pengaruh Earning Per Share terhadap Harga Saham pada perusahaan Farmasi yang terdaftar di Bursa Efek Indonesia. Hasil uji secara parsial menunjukkan bahwa nilai thitung untuk variabel Earning Per Share adalah 0,572 dan $t_{\text {tabel }}$ dengan $\alpha=5 \%$ diketahui sebesar 2.026. Dengan demikian $(0,572<2.026)$ dan nilai signifikan sebesar 0,571 (lebih besar dari 0.05) artiya $\mathrm{H}_{\mathrm{o}}$ diterima dan $\mathrm{H}_{\alpha}$ ditolak. Berdasarkan hasil tersebut maka disimpulkan bahwa ada pengaruh positif dan tidak signifikan antara Earning Per Share terhadap Harga Saham.

Menurut Kasmir (2010, hal. 115) Earning Per Share merupakan rasio untuk mengukur keberhasilan manajeman dalam mencapai keuntungan bagi pemegang saham. Rasio ini rendah berati manajeman belum berhasil untuk memuaskan pemegang saham, sebaliknya rasio yang tinggi, maka kesejahteraan pemegang saham meningkat. Rasio yang rendah berati manajemen belum berhasiluntuk memuaskan pemegang saham, sebaliknya dengan rasio yang tinggi, maka kesejahteraan pemegang saham meningkat dengan pengertian lain, bahwa tingkat pengembalian tinggi.

Hasil ini didukung oleh penelitian yang mengatakan bahwa Earning Per Share memiliki pengaruh positif terhadap Harga Saham (Utami, 2018;Sriwahyuni \& Saputra, 2017 ; Pratama \& Erawati 2014) dapat disimpulkan bahwaEarning Per Share berpengaruh positif terhadap harga saham.

Namun hasil penelitian ini tidak sejalan dengan penelitian yang mengatakan bahwa secara parsial Earning Per Share tidak berpengaruh terhadap harga saham ( Raharjo \& Muid, 2013 ; Darnita, 2016 ; Rani \& Dianiti, 2015). Dapat disimpulkan bahwa Earning Per Share berpengaruh negatif terhadap harga saham. 


\section{Pengaruh Debt to Asset Ratio, Return on Investment, dan Earning Per Share terhadap Harga Saham}

Hasil pengujian secara simultan, maka dapat diperoleh nilai $F_{\text {hitung }}$ sebesar 3.077 dan $F_{\text {tabel }}$ diketahui sebesar 2.87.Berdasarkan hasil tersebut maka dapat diketahui bahwa $F_{\text {hitung }}>$ $\mathrm{F}_{\text {tabel }}\left(3.077>2.87\right.$ ), dan signifikansi adalah sebesar 0.040(lebih kecil dari 0.05) ini berarti $\mathrm{H}_{\mathrm{o}}$ ditolak dan $\mathrm{H}_{\mathrm{o}}$ diterima. Jadi dapat disimpulkan bahwa variabel Debt to Asset Ratio, Return on Investment, dan Eaning Per Share secara simultan berpengaruh signifikan terhadap Harga saham pada perusahaan Farmasi yang terdaftar di Bursa Efek Indonesia.

Hasil ini sejalan dan didukung penelitian yang menyimpulkan bahwa Debt to Asset Ratio (DAR), Return on Investemnt (ROI), dan Earning Per Share (EPS) berpengaruh signifikan secara simultan terhadap harga saham (Pratama \& Erawati, 2014; Rimbani, 2016 ; Khoi \& Handayani 2017) dapat disimpulkan bahwa secara silmutan terdapat pengaruh yang signifikan antara Earning Per Share, Debt to Equity Ratio, dan Return on Investemnitterhadap harga saham.

\section{Kesimpulan dan Saran \\ 5.1 Kesimpulan}

Berdasarkan hasil penelitian yang telah diperoleh maupun hasil analisis atau pembahasan yang telah dikemukakan pada bab sebelumnya, maka dapat diambil kesimpulan mengenai Pengaruh Debt to Asset Ratio, Return on Asset, dan Earning Per Share terhadap Harga Saham pada perusahaan Farmasi yang terdaftar di Bursa Efek Indonesia periode maka dapat disimpulkan bahwa secara parsial tidak berpengaruh dan tidak signifikan Debt to Asset Ratio terhadap hargasaham, secara parsial berpengaruh negatif dan sifnifikan Return on Investemntterhadap harga saham. secara parsial berpengaruh positif dan tidak sifnifikan Earning Per Share terhadap harga saham, secara simultan berpengaruh signifikan terhadap harga saham antara Debt to Asset Ratio, Return on investment, dan Earning Per Share terhadap harga saham, dan nilai koefesien determinasi adalah sebesar 20,4\%

\subsection{Saran}

Berdasarkan keterbatasan diatas, maka dalam penelitian ini diajukan saran sebagai berikut Perusahaan harus mengurangi penambahan hutang dan lebih meningkatkan ekuitas bagi pemegang saham, sehingga keuntungan yang dihasilkan oleh perusahaan akan meningkatkan dan perusahaan dapatmenanggung kerugian tanpa harus membahayakan kreditor. Karna semakin tinggi total kewajiban semakin besar beban peusahaan dibandingkan dengan total modal sendiri sehingga semakin besar beban perusahaan terhadap pihak luar. Sebaiknya perusahaan juga dapat meningktkan penjualannya atau meningkatkan harga produk penjualannya. Hal tersebut dapat meningkatkan ketertarikan dan kepercayaan investor untuk menanamkan dananya, pada perusahaan pun dapat dipertahankan karena investor dapat menilai bahwa perusahaan cukup profit. Sebaiknya perusahaan dapat meningkatkan laba bersih dengan cara mengurangin biaya oprasional dan biaya produksinya. Sehingga laba yang cukup tinggi mempengaruhi nilai laba per lembar saham yang tinggi yang akan dibagikan pada para investor, sehingga meningkatkan kepercayaan investor terhadap perusahaan. Sebaiknya perusahaan memperhatikan kinerja manajemen perusahaan dalam hal Debt to Asset Ratio, Return on Investment, Earning Per Share untuk mencapai tujuan perusahaan. jika para investor ingin menanamkan sahamnya kepada pihak yang ingin melakukan investasi sebaiknya para investor lebih memperhatikan faktor-faktor yang mempengaruhi harga saham. Penulis juga menyarankan untuk penelitian selanjutnya diharpkan untuk menggunakan periode penelitian yang lebih panjang dan menambah variabel-variabel yang lebih berpengaruh terhadap harga saham. 


\section{Referensi}

Alfiah, dkk. (2017). "Pengaruh ROE DAR terhadap harga saham pada sektor perdagangan eceran”. Jurnal Bisnis Terapan. 1(2); 49-53

Arisma, Y. (2012). "Faktor-faktor yang mempengaruhi harga saham perusahaan perbankan yang listing di BEI". Jurnal sosial ekonomi pembangunan. 2(5); 160-163.

Aryani, dkk. (2016). "Pengaruh Ratio profitabilitas terhadap harga saham pada perusahaan industri logam \& sejenisnya yang terdaftar di BEI 2011-2017'. Jurnal Akuntansi. 4(1); 27-29.

Azmi,dkk. (2016). "Pengaruh Net Profit Margin, Return On Assets dan Current Ratio terhadap harga saham Emiten LQ45 yang terdaftar di Bursa Efek Indonesia pada periode 20102014". Jurnal of accounting. 2(2); 1-6.

Batubara, HC. (2017). "Pengaruh Return On Assets (ROA), Return OnEquity (ROE), dan Debt to Asset Ratio (DAR) terhadap harga sahamperusahaan makanan dan minuman yang terdaftar di Bursa Efek Indonesia Periode 2011-2015”. Jurnal Ilmiah Kohesi. 1(1); 69-73.

Dewi, dkk(2013). "Pengaruh EPS, DAR, dan PBV terhadap harga saham". E-Junal Akuntansi Universitas Udayana.4(1); 222-227.

Egam, dkk(2017). "Pengaruh Return On Asset (ROA0), Return On Equity (ROE), Return on Investemnt(ROI), dan Earning Per Share (EPS), terhadap harga saham perusahaan yang tergabung dalam indeks LQ45 di Bursa Efek Indonesia periode tahun 20132015”. Jurnal EMBA. 5(1); 109-113.

Fahmi, I. (2017) “Analisis Laporan Keuangan". (cetakan keenam). Bandung: Alfabeta.

Fahmi, Irham. (2015) "Pengantar Teori Portofolioan Anlisis Investasi".

Bandung: Alfabeta.

Hutami, RP. (2012). "Pengaruh Dividend Per Share, Return On Equity dan Return on Investemnttehadap harga sahamm pada peusahaan industri manufaktur yang tercatat di Bursa Efek Indonesia Peiode2006-2010". Jurnal Nominal. 1(1); 112-120.

Kasmir, K (2010). "Pengantar Manajemen Keuangan" (cetakan ke-4). Jakarta: Prenadamedia Group.

Kasmir, K (2015). “Analisis Laporan Keuangan”. (cetakan kedelapan). Jakarta:Grafindo Persada.

Khoir, dkk. (2017). "Pengaruh Earning Per Share, Return On Asset, Net Profit Margin, Debt to Asset Ratio terhadap harga saham". Jurnal Ilmiah Kohesi. 5(1); 6- 10.

Pratama , Aditya dan Teguh Erawati. (2014). "Pengaruh Current Ratio, Debtto Equity Ratio, Return on InvestemntDan Earning Per Share terhadap harga saham". Jurnal Akuntansi. $2(1) ; 1-7$.

Rani, K. dkk (2015). "Pengaruh kinerja keuangan perusahaan terhadap harga saham pada indeks LQ45 di BEI”. E- jurnal manajemen. 4(6); 1532-1538.

Raharjo, D dan Dul M. (2013). "Analisis pengaruh fakto-faktor fundamental rasio keuangan terhadap harga saham". Jurnal of Accounting. 2(2); 1-9.

Rimbani, RP. (2016). “Analisis Pengaruh ROA, EPS, PBV, DAR, dan ROI terhadap Harga Saham pada Perusahaan Real Estate dan Proferty di Bursa Efek Indonesia Periode 2011-2013". Jurnal Bisnis dan Manajemen. 53(12); 199-205.

Situmeang, C. (2014) . "Manajemen Keuangan”. Medan: Unimed.

Sriwahyuni, E dan Rishi S. (2017). "Pengaruh CR, DAR, ROE, TAT, dan EPS Terhadap Harga Saham Industri Farmasi di BEI Tahun 2011-2015”. Junal Ilmiah Kohesi. 1(1); 126-134.

Utami, M dan Arif D. (2018). "Pengaruh DAR, ROE, EPS dan MVA terhadap Harga Saham pada indeks saham syariah Indonesia". Jurnal of Applied managerial Accounting. 2(2); 81-89 